\title{
OD DESKRYPCJI OKREŚLONEJ DO ERGONIMU — GALICYJSKIE NAZWY PRZEDSIĘBIORSTW
}

Słow a tematyczne: Galicja, ergonim, deskrypcja, ogłoszenia prasowe

\section{UWAGI WSTĘPNE}

Współcześnie zasady nadawania nazw firmom są ściśle określone. Osoba fizyczna, zakładając firmę, musi wypełnić druk CEIDG-1. W punkcie 6. powinna wskazać oznaczenie przedsiębiorcy, które obowiązkowo musi zawierać jego imię i nazwisko ${ }^{1}$. Ważny jest jednak fakt, że nazwa samej siedziby firmy może być inna niż jej urzędowa postać (np. zakład fryzjerski może się nazywać Nowy Styl, a firma Ustugi fryzjerskie. Anna Kowalska). Nieco inne są zasady nadawania nazw spółkom cywilnym $^{2}$ i spółkom z ograniczoną odpowiedzialnością ${ }^{3}$.

Przedmiotem dalszych rozważań nie będą jednak nazwy firm funkcjonujących współcześnie, ale działających w tzw. okresie galicyjskim, czyli w czasie od rozbiorów do wybuchu pierwszej wojny światowej. Ogólnie sądzi się, że Galicja była obszarem ubogim i zaniedbanym pod względem rozwoju przemysłowego, niemal pozostawionym przez zaborcę na pastwę losu. Jak podkreślają jednak ekonomiści, „bodźcem do rozwoju tego regionu” były działające tu drobne in-

${ }^{1}$ W objaśnieniach do formularza czytamy: ,Firmą osoby fizycznej jest jej imię i nazwisko. Nie wyklucza to włączenia do firmy pseudonimu lub określeń wskazujących na przedmiot działalności przedsiębiorcy, miejsce jej prowadzenia oraz innych określeń dowolnie obranych" (https://prod.ceidg.gov.pl/ CEIDG/CEIDG.Public.UI/Forms/CEIDG1.aspx?type=1).

2 Według wytycznych: „Zgodnie z art. 43 k.c. [...] w razie gdy członkami spółki cywilnej są osoby fizyczne [...], nazwa spółki cywilnej powinna zawierać co najmniej imiona (ewentualnie ich pierwsze litery) i nazwiska wszystkich wspólników, ze wskazaniem, że zawarli oni spółkę cywilną (np. poprzez określenie spółka cywilna bądź jego skrót). Poza tym w nazwie spółki umieścić można określenie wskazujące na przedmiot działalności, miejsce jej prowadzenia czy inne dowolnie dobrane elementy" (http:// www.zakladamyfirme.pl/artykul_narzedziowa,643,643,646,spolka-cywilna-najtansza-w-zalozeniu-iprowadzeniu.html).

${ }^{3}$ Nazwa spółki z o.o. może być obrana dowolnie; powinna jednak zawierać dodatkowe oznaczenie „spółka z ograniczoną odpowiedzialnością” (http://www.sp-z-oo.pl/). 
stytucje handlowe (Kruk 2015: 93; por. też Mianowski 1938). Należy przy tym podkreślić, że:

W rozumieniu ówczesnego prawa przemysłowego przemysłem był nie tylko przemysł w znaczeniu ekonomiczno-społecznym, ale także handel, przewóz i pośrednictwo, niekiedy też inne zajęcia zarobkowe. Niektórzy niemieccy ekonomiści (np. Raul) rozumieli przez przemysł wszelką działalność zarobkową (Kruk 2015: 94).

Równie szeroko jak pojęcie firmy przemystowej będzie w tym opracowaniu potraktowany termin ergonim ${ }^{4}$. Obejmuje się nim tutaj nie tylko nazwy instytucji handlowych wszelkiego rodzaju, przedsiębiorstw wytwórczych i usługowych, ale również nazwy firm oferujących usługi edukacyjne, transportowe, finansowe itp. Zebrany materiał ma charakter sondażowy, podobnie jak poczynione poniżej uwagi.

Do analizy wybrano materiał pochodzący z ogłoszeń prasowych o charakterze informacyjno-reklamowym $\mathrm{z}$ trzech ważnych galicyjskich czasopism: „Czasu”, ukazującego się w Krakowie (wykorzystano roczniki 1850-1910) ${ }^{5}$, „Gazety Lwowskiej" (roczniki 1870-1910 i — dla porównania — kilka numerów z okresu międzywojennego) ${ }^{6}$ oraz „Głosu Rzeszowskiego” (lata 1897-1920)7. Wybór przedziałów czasowych był podyktowany względami praktycznymi - we wcześniejszych numerach zamieszczano co najwyżej (a i to rzadko) pojedyncze ogłoszenia reklamowe; we wskazanych tutaj — całe strony pełniły funkcję swoistej „tablicy ogłoszeń". Tuż przed wybuchem pierwszej wojny zrezygnowano z drukowania reklam, ale później do tego powrócono. Zebrany materiał obejmuje 397 jednostek, z czego 151 to określenia wynotowane z periodyku lwowskiego, 196 - z krakowskiego, a 50 - z rzeszowskiego. Mimo iż są to — jak wspomniano — ogłoszenia reklamowe, w tym opracowaniu skupiono się tylko na analizie nazw; opis strategii reklamowych przekracza ramy tego artykułu.

Niestety, w opisywanym okresie nie istniały przepisy prawne dotyczące zasad nazywania firm. W dobie autonomii (a z tego okresu pochodzi większość analizowanych tu nazw) w Galicji na politykę przemysłową miały wpływ samorząd gospodarczy oraz stowarzyszenia, związki przemysłowe i towarzystwa wspierające przemysł. Pierwsza $\mathrm{z}$ tych instytucji, samorząd gospodarczy, powstała w drugiej połowie XIX w., a jej zadaniem był nadzór nad równomiernym rozwojem przemysłu i całej gospodarki regionu. Ważnymi instytucjami, które powołano do życia

${ }^{4}$ Nazwy firm, produktów i usług bywają określane terminami: nazwy handlowe, firmonimy, ergonimy komercyjne albo też określane opisowo (nazewnictwo marketingowe, nazwy obiektów handlowoustugowych), lub metaforycznie (nazwy na sprzedaż) (por. Gałkowski 2011: 37). Dla nazw placówek handlowych A. Siwiec (2012: 38-43) zaproponował termin emporionim, w tym ujęciu wydaje się on zbyt wąski, dlatego pozostanę przy terminie ergonim jako najbardziej ekonomicznym, a zarazem pojemnym.

${ }^{5} \mathrm{http}: / / \mathrm{mbc}$.malopolska.pl/dlibra/publication?id $=36972 \& \mathrm{tab}=3$

${ }^{6} \mathrm{http}: / /$ jbc.bj.uj.edu.pl/dlibra/publication?id $=10709 \& \mathrm{tab}=3$

${ }^{7} \mathrm{http}: / /$ www.pbc.rzeszow.pl/dlibra/publication?id=1934\&from=\&dirids=1\&tab=1\&lp=15\&QI 
w 1850 r., były izby handlowe i przemysłowe (od 1868 r. izby przemysłowo-handlowe - na obszarze Galicji utworzono trzy, z siedzibami w Krakowie, Lwowie i Brodach). Wśród wielu zadań izb (ustawodawstwo, ochrona handlu, dbanie o interesy handlowców, reprezentacje w sejmie itp.) nie było takich, które dotyczyłyby nazewnictwa, ale izby miały obowiązek prowadzenia rejestru osób mających uprawnienia wyborcze oraz rejestru wzorów i marek produktów przemysłowych (por. Kruk 2015: 96-99).

Inną ważną organizacją był powstały w 1903 r. Centralny Związek Galicyjskiego Przemysłu Fabrycznego. Jego głównym celem było ,,przestrzeganie wspólnych interesów przemysłu krajowego" (Kruk 2015: 100). Ponadto związek miał pełnić funkcje doradcze, pomagać w organizowaniu sprzedaży, mobilizować do zakładania nowych przedsiębiorstw. Podobnie jak izby przemysłowo-handlowe, nie nadzorował on nazywania firm. Także powołana do życia w 1903 r. Liga Pomocy Przemysłowej nie była organem kodyfikującym nazewnictwo. Do jej zadań należało raczej ,,popieranie wspólnych interesów i rozwoju Towarzystwa Pomocy Przemysłowej oraz towarzystw zawiązanych dla obrony i podniesienia krajowego przemysłu, rolnictwa i handlu" (Kruk 2015: 101).

Brak norm w zakresie nadawania nazw pozostawiał przedsiębiorcom pewną swobodę, której jednak — jak postaram się wykazać w dalszej części tekstu zbytnio nie wykorzystywano. Analiza nazw na podstawie ogłoszeń prasowych nastręcza zresztą badaczowi sporo problemów. Podstawowa trudność polega na wyodrębnieniu z ogłoszenia samej nazwy, bo nie zawsze wskazuje na nią ortografia czy wielkość bądź krój czcionki. Obok ogłoszeń, w których dość łatwo wydzielić nazwę (np. HANDEL TOWARÓW KORZENNYCH Juliusza Holzera - fot. nr 1) oraz takich, w których jest to określone wprost (ZAKŁAD FOTOGRAFICZNY pod firmą Zofia i Janina Staszczakówny — fot. 2), odnajdujemy takie, w których trudniej wskazać, co jest „tylko" reklamą produktów czy usług, a co — nazwą firmy (zob. fot. 3-6). Pojawiają się też oryginalne w swej formie anonsy, w których na przykład nazwisko właściciela firmy jest zapisane w cudzysłowie (fot. 7).

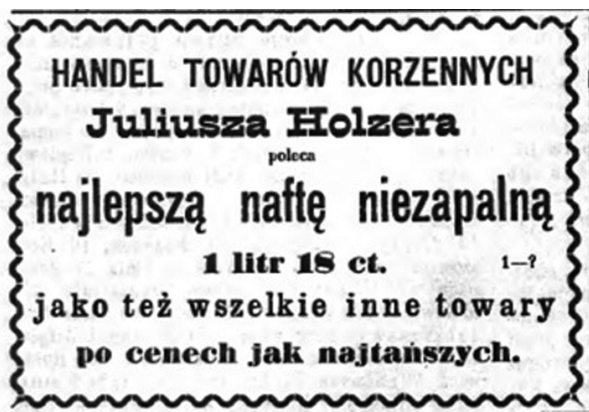

Fot. 1. GR 1, 1897, nr 6, s. 4

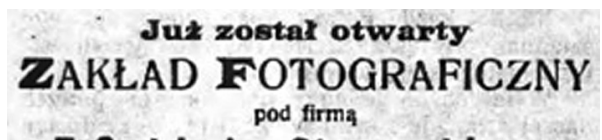

Zofia i Janina Staszczakówny.

Nowo otworzony Zakład wedhug wszelkich wymo. gów artystycznych w umysinie wybudowanym salonie przy placu farnym w ogrodzie Hurtowni Kupeów, poleca się P. T. Publicznosci. Wykonanie artystyczne, odpowiadajace najwybredniejszym wymogom. : $:$ - Ceny nader przystępne.

Fot. 2. GR 23, 1920, nr 28, s. 2 


\section{TOUARY POZHOTNICAS}

machinowa Fabryka zlota dającego slę myé, polltury, opraw 1 ram

Ingeniussa Irarte
Fot. 3. CK 1870, nr 4

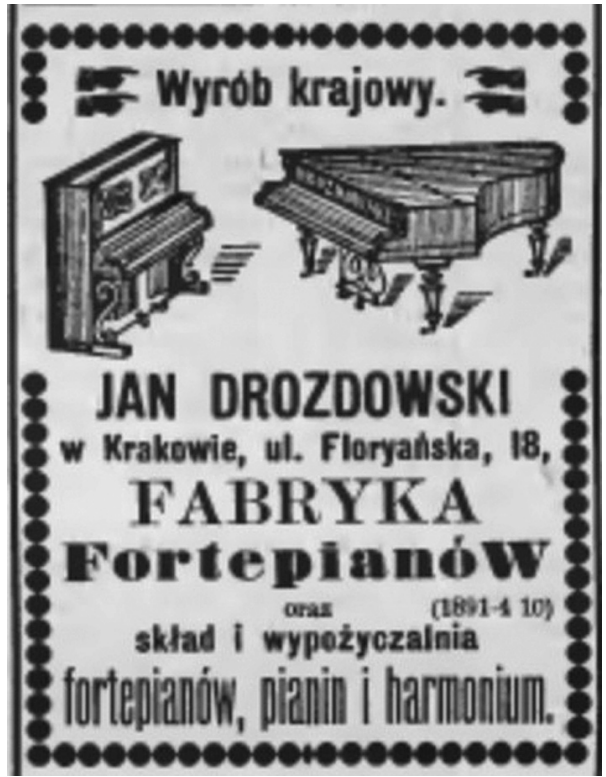

Fot. 5. CK 1900, nr 90

\section{Obicia pokojowe (tapety)}

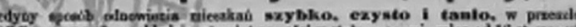

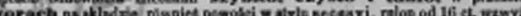

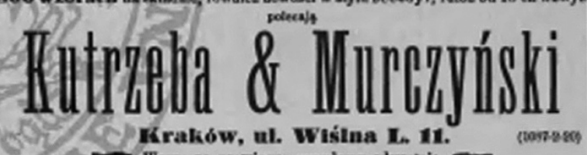

7 Weoy at peowibrys wyoglang eduretaie

Fot. 4. CK 1890, nr 201

\section{WILHELM PENTHER} zegaxmistrez,

We Lwowie nlica Halleka pod 1. 281 stara 17 now. m. poleca Szanownej Publiczności najiwiękrzy

SKXAD ZEGARÓW

we Lwowie, skladajacy sie z aszelkiego rodzaju zegaroite najlepszej jakosci po najtanszych stahych cenach.

Każdy zegarek obciąga sieg jak najstaranniej i ulziela sie za akuratność biegu całoroczną rękojmie.

Wszelkie naprawy przjjwuja slę f wykeauja jak najlepirj.

\section{Jeclyng ma Gallaje}

OIEX

prawodsiwych amerykańskich segarków kotwicsnych

₹tro z chińskiego srebra "Remontoirs" (bez kluezyka do nakregeania)

Łańcuszków srebrnych i zkotych (3478 2-3) utrzymuje wielki zapas po miernych cenach.

Fot. 6. GL 1872, nr 291

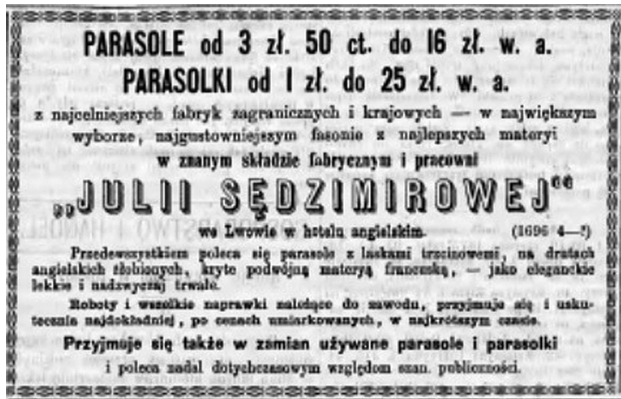

Fot. 7. GL 1873, nr 141 
Celem analizy w dalszej części artykułu jest ukazanie, jak w XIX w. kształtowało się nazewnictwo firm, jakie elementy rzeczywistości pozajęzykowej najczęściej stawały się komponentami ergonimów, jak były zbudowane te nazwy. Przede wszystkim postaram się jednak pokazać ewolucję w tej grupie nazw w ciagu kilkudziesięciu lat okresu autonomii. Niestety, niewiele dawnych drobnych przedsiębiorstw galicyjskich przetrwało „upaństwowienie” w latach 1945-1989, a potem uległo reprywatyzacji, dlatego ewolucję nazw do czasów współczesnych można obserwować tylko na pojedynczych przykładach.

\section{BUDOWA I MOTYWACJA NAZW}

Przeprowadzona analiza wykazała, że motywacja nazw w dużym stopniu determinuje ich strukturę, toteż w badanym materiale można wyróżnić kilka modeli motywacyjno-strukturalnych o różnej produktywności. Przede wszystkim należy wydzielić dwie duże grupy nazw przedsiębiorstw:

I. Nazwy, w których utrwalono nazwisko (nazwiska) właściciela.

II. Nazwy niezawierające nazw osobowych.

Są to bardzo nierówne grupy. Pierwsza obejmuje $85 \%$ analizowanych zapisów, druga - 15\%. Szczegółowy podział nazw zamierzam przedstawić w innym miejscu ${ }^{8}$, tu poprzestanę na kilku przykładach i uwagach ogólnych.

\section{I.1. Ergonim = antroponim}

W 57 (14\%) ogłoszeniach firmy są desygnowane wyłącznie nazwiskiem właściciela, co czasami bywa podkreślane słowami firma, pod firma, pod nazwa, a nazwisku towarzyszy opis branży albo sprzedawanych produktów, np. ${ }^{9}$ :

S. Gabriel \& J. Chlebownik we Lwowie [...] polecają najnowsze krawaty (GL 80, 1890, nr 282, s. 12).

Nowo założony magazyn pod firmą B. Mikuliński i L. Krokowski we Lwowie (wielki skład sukna) (GL 80, 1890, nr 62, s. 12).

PAPIERY Listowe i kancelaryjne Bibuły, Atrament, Pióra przedaje najtaniej FIRMA TEOFIL BĘKNER (CK 63, 1910, nr 405, s. 4).

Magazyn bławatny pod nazwą Józef Neuwert i Syn w Krakowie (CK 43, 1890, nr 252, s. 6).

Trudno w takim przypadku mówić o właściwej nazwie firmy, raczej jest to swoista transonimizacja, polegająca na sygnowaniu firmy antroponimem (określona jednostka prymarnie pełni funkcję antroponimu, sekundarnie - ergonimu). Poniekąd wynika to z samego znaczenia słowa firma, które etymologicznie jest

${ }^{8}$ Artykuł złożony do czasopisma „Słowo. Studia językoznawcze”.

9 We wszystkich cytowanych przykładach zachowuję ortografię oryginału, w tym stosowanie wielkich i małych liter oraz kapitalików. Nie jestem w stanie zachować pogrubień, rozmiaru i kroju czcionki, które to elementy też mają znaczenie przy wyodrębnianiu nazwy firmy. 
związane z włoskim firma, oznaczającym 'podpis potwierdzający; potwierdzenie umowy podpisem', a to z łac. firmus 'silny, trwały' (SEB I 372; por. też SWO 270). Słownik warszawski, który powstawał w okresie notacji analizowanych tu nazw, w definicji wyrazu firma akcentuje, że jest to nazwa handlowa, w skład której wchodzi nazwisko, ale też — w przenośni - oznacza czyjeś nazwisko, reputację ${ }^{10}$. Podobną definicję odnajdziemy w pół wieku późniejszym słowniku pod redakcją W. Doroszewskiego, który dodatkowo akcentuje, że firma oznacza nazwę urzędową $^{11}$. Autor słownika podaje przykłady, z których wynika, że wyraz firma był równoznaczny z nazwą, nazwiskiem („Powiedział mu ktoś plotkę, której uwierzył, że ja zawsze prowadzę mój handel hurtowny, tylko pod inną firmą" — SJPDor II 890). Ślady dawnego powiązania wyrazów firma - nazwa - nazwisko odnajdujemy do dziś m.in. w wyrażeniu firmować coś swoim nazwiskiem, czyli 'wspierać jakieś przedsięwzięcie swoim autorytetem albo marką firmy', ale też 'umieszczać swoje nazwisko albo nazwę firmy na wyrobach', 'podpisywać dokument swoim nazwiskiem’ (http://sjp.pwn.pl/slowniki/firmować.html; SJPDor II 890).

\section{I.2. Ergonim = antroponim + określenie branży}

Więcej jest ogłoszeń, w których obok nazwiska właściciela (właścicieli) w mianowniku pojawiają się określenia branży. Tak zbudowane ergonimy mają raczej charakter deskrypcji określonych niż nazw właściwych, ale są dosyć umiarkowanie zmienne, powtarzalne w kolejnych ogłoszeniach i w kolejnych latach. Stanowią więc swoiste preteksty ${ }^{12}$, poprzedzające uformowanie się właściwej nazwy, już oficjalnej, urzędowej, objętej ochroną prawną. W analizowanym materiale takich nazw jest 86 (więcej niż co piąta). W niemal połowie tego typu zapisów podawana jest tylko branża czy rodzaj przedsiębiorstwa, np.:

Fryderyk Mroziński SKŁAD i pracownia FUTER [...] we Lwowie przy ulicy Sobieskiego liczba 7 (GL 70, 1880, nr 292, s. 10).

Fabryka Pieców kaflowych Józef Dunikowski i Sp. w Zakrzówku (CK 43, 1890, nr 10, s. 4).

DOM BANKOWY BLAU \& EPSTEIN w Krakowie (CK 43, 1890, nr 127, s. 4).

$\mathrm{W}$ innych ogłoszeniach zawarte są dodatkowe informacje reklamujące dany zakład, np.:

${ }^{10}$ Por. firma 'miano handlu, przedsiębiorstwa, urzędowa jego nazwa z nazwiska właściciela a. godła złożona'; przen. 'handel, przedsiębiorstwo, zakład oznaczony firmą', 'nazwisko czyjeś, reprezentujące jaką́s sprawę, pracę, reputacja ustalona' (SW I 746).

${ }^{11}$ Por. firma 'przedsiębiorstwo handlowe lub przemysłowe', 'zarejestrowana, urzędowa nazwa przedsiębiorstwa handlowego lub przemysłowego', przen. 'czyjeś nazwisko reprezentujące coś, ustalona reputacja, czyjaś dobra sława' (SJPDor II 889-890).

12 Termin pretekst został wprowadzony przez M. Rutkiewicz-Hanczewską (2013: 14) na oznaczenie struktury nazewniczej, z której w najbliższym czasie może (ale nie musi) powstać właściwa nazwa własna. 
MAGAZYN MEBLI Firmy stolarskiej założonej w roku 1842 Bolesław Haszczyński (Lwów) (GL 1900, nr 195, s. 12).

HEILMANN KOHN i SYNOWIE pierwszorzędny wiedeński dom konfekcji męskiej i dziecięcej oraz uniformów dla p.p. Studentów w Rzeszowie (GR 14, 1910, nr 25, s. 4).

Mrs. Emil Reisner pierwszy i najsłynniejszy wiedeński zakład guwernantek (CK 43, 1890, nr 201, s. 4).

Bardziej proprialny charakter mają nazwy, w których podany jest rodzaj obiektu i nazwisko właściciela w dopełniaczu. Niestety, określenia te są tylko względnie stałe, co wciąż zbliża je do deskrypcji. Ich ogromna liczba skłania jednak do stwierdzenia, że są pewnym w miarę trwałym modelem nazw firm w Galicji w dobie autonomii. Aż 171 (43\%) analizowanych tu zapisów zawiera określenia o strukturze 'rodzaj firmy, branża + nazwisko właściciela w genetivie', np.:

Herbaty chińskie [...] tylko w handlu Stanisława Markiewicza we Lwowie (GL 65, 1875, nr 4, s. 8).

Drukarnia Wł. Łozińskiego (GL 80, 1890, nr 10, s. 10).

Księgarnia J.A. Pelara w Rzeszowie (GR 1, 1897, nr 1, s. 4).

Biuro umieszczeń Justyny Jędrzejewskiej w Krakowie (zawiadamia osoby interesowane, iż są do umieszczenia Guwernerowie, Guwernantki i Bony ..) (CK 23, 1870, nr 283, s. 4).

Czasami temu modelowi towarzyszą dookreślenia o funkcji reklamowej, co oczywiście nie może dziwić w ogłoszeniach prasowych, np.:

Największa w kraju CZYTELNIA KAROLA WILDA we Lwowie (GL 70, 1880, nr 201, s. 10).

Najlepszej jakości PŁÓTNA i BIELIZNĘ STOŁOWĄ [...] poleca znany skład ED. OBERLEITHNERA S YNÓ W we Lwowie (GL 80, 1890, nr 282, s. 12).

C.k. nadworna i uprzywilejowana Fabryka Obówia Leopolda Hahna w Wiedniu (CK 23, 1870, nr 1, s. 4).

\section{I.3. Ergonim = antroponim + właściwa nazwa}

Dopiero pod koniec XIX w. zaczynają się pojawiać właściwe firmonimy. Często są one wydzielane cudzysłowem, zazwyczaj (ale nie zawsze) ta „nazwa w nazwie” jest też wyodrębniana typograficznie: wielkimi literami, pogrubieniem, inną czcionką czy rozmiarem liter. W badanym materiale można wskazać 23 jednostki składające się $\mathrm{z}$ antroponimu połączonego z właściwą nazwą (blisko 6\%). Modę na ten model zapoczątkowały — jak się wydaje — apteki, które od dawna miały swoje godła ${ }^{13}$, np.:

APTEKA pod godłem „Matki Boskiej” (Józef Kołodziejowski, Rzeszów, Nowe Miasto) (GR 1, 1897, nr 3, s. 4).

apteka ,pod Złotym orłem” J. Nahalika, przedtem Millinga we Lwowie (GL 70, 1880, nr 2, s. 9).

Apteka ,pod Gwiazdą” Konstantego Wiszniewskiego w Krakowie (CK 33, 1880, 100, s. 4).

Apteka „Pod Koroną” w Krakowie Józefa Trauczyńskiego (CK 43, 1890, nr 255, s. 4).

Apteka pod orłem A. Blumenthala w Żywcu-Zabłociu (CK 33, 1880, nr 230, s. 4).

${ }^{13}$ Por. opis nazw rzeszowskich i krakowskich aptek: Górny 2003, 2005; także Pabis-Braunstein 1986. 
W innych typach przedsiębiorstw moda na takie miana pojawiła się z pewnym opóźnieniem. I choć nazw tych nie było bardzo dużo, w niektórych już można obserwować ciekawe skojarzenia, a nawet elementy gier językowych często pojawiających się we współczesnych ergonimach (np. gra pomiędzy brzmieniem a grafią w nazwie Berson, utworzonej od połączenia Beer \& Söhne):

„Berson” Sigmund Beer\&Söhne (obcasy gumowe ) (CK 63, 1910, nr 60, s. 6).

Inne przykłady nazw tego typu odnajdujemy w zapisach:

„NORIS” zakład przemysłowy wyrobów papierowych i tutek cygar W. BEŁDOWSKIEGO (CK 53, 1900, nr 1, s. 6).

FABRYKA opatrunków chirurgicznych „VIS” (Mra. M.L. Dobrowolskiego) w Podgórzu-Krakowie (CK 63, 1910, nr 54, s. 4).

Hurtownia przyborów do palenia „L'Etoile” Michał Hackel (GL 110, 1920, nr 174, s. 8).

SKŁAD KAWY ARTURA KOSCICKIEGO pod godłem SYRIUSZ we Lwowie (GL 80, 1890, nr 11, s. 10).

W tej grupie mian znajdziemy także takie, których człony akcentują tradycje danego miejsca, charakter towarów, ich pochodzenie, np.:

Wydawnictwo Księgarni Polskiej B. Połonieckiego we Lwowie (GL 100, 1910, nr 6, s. 12). CUKIERNIA LWOWSKA JANA MICHALIKA w Krakowie (CK 53, 1900, nr 2, s. 6).

Warto ponadto zwrócić uwagą na człony lokalizujące, przybierające postać adiektywną, co akcentuje położenie jako właściwość, cechę obiektu, np.:

Teatr Krakowski pod dyrekcją Juliusza Pfeiffera (CK 13, 1860, nr 280, s. 4).

Mydlnicka fabryka wapna i kamieniołomy BRACIA KAMSLER \& M. DEMBITZER (CK 43, 1890, nr 201, s. 4).

II. Ergonimy niezawierające antroponimów

Tylko co siódma odnotowana w gazetach galicyjskich nazwa (59, czyli około $15 \%$ ) nie zawiera nazwiska właściciela firmy. Są w tej grupie zarówno miana z połowy XIX, jak i z początku XX w., nie należy zatem motywacji wiązać z czasem notacji. Mało prawdopodobne, że w przypadku tej grupy firm właściciel nie chce się ujawniać. Raczej należy to tłumaczyć tym, że właściciel jest zbiorowy. Na taką motywację wskazują nazwy typu:

Stowarzyszenie „Pracy Kobiet” (pracownia krawiecka, biuro pośrednictwa pracy itp. — Lwów) (GL 70, 1880, nr 290, s. 10).

SKŁAD MEBLI Spółka stolarzy lwowskich we Lwowie (GL 80, 1900, nr 45, s. 12).

Spółka tkacka w Krośnie (przy krajowej szkole zawodowej dla nauki tkactwa) (CK 43, 1890, r. 43, nr 125, s. 4). 
Miana z tej grupy mogą wskazywać wyłącznie na rodzaj (specyfikację) firmy. Dotyczy to zwłaszcza banków i towarzystw kredytowych, ale także drobnych zakładów produkcyjnych, np.:

Towarzystwo Wzajemnego kredytu w Krakowie (GL 100, 1910, nr 2, s. 14).

Bank Rolniczy we Lwowie (GL 80, 1890, nr 11, s. 10).

Towarzystwo Zaliczkowe w Krośnie (CK 33, 1880, nr 101, s. 6).

Wyrobnia Oleju skalnego w Klęczanach (CK 13, 1860, nr 280, s. 4).

„Biuro umieszczeń guwernantek i bon w Krakowie” (CK 43, 1890, nr 2, s. 4).

W wielu nazwach zawarte są informacje nie tylko o specyfikacji firmy, ale także o jej lokalizacji lub zasięgu:

Wiedeńskie Towarzystwo Kantoru Wymiany (CK 23, 1870, nr 283, s. 4).

Lwowski akcyjny Zakład zastawniczy (GL 100, 1910, nr 40, s. 14).

Bank Galicyjski dla Handlu i Przemysłu (GL 65, 1875, nr 2, s. 8).

c.k. Obwodowa apteka w Rzeszowie (3 maja) (GR 21, 1918, nr 1, s. 4).

W strukturze nazw niezawierających antroponimów już w trzeciej ćwierci XIX w. pojawiają się linkteksty ${ }^{14}$. Jest ich relatywnie sporo, bo aż 28 (blisko połowa tej grupy). Większość mian informuje o specyfikacji firmy, a człon ujęty w cudzysłów dookreśla zasięg, charakter, wskazuje na asocjacje, np.:

Zakład pośredniczący „GERMANIA” w Wrocławiu (Prusy) — zakład pośrednictwa pracy (GL 65, 1875 , nr 5, s. 8).

Spółka handlowa „ORIENT” we Lwowie (towary dla rolnictwa i przemysłu, towary kolonialne) (GL 70, 1880, nr 101, s. 10).

Fabryka maszyn roln. „ODLEW” w Krakowie, Spka z ogr. Odpow. (dawniej Petersiem) (GR 21, 1918, nr 40, s. 2).

„Vesta” Bank Wzaj. Ubezpieczeń w Poznaniu Oddział Lwowski (GL 110, 1920, nr 1, s. 6).

Gorsety „FELICYA” Kraków (CK 63, 1910, nr 54, s. 4).

Oczywiście, model ten występował też we wcześniejszych grupach, ale tam w skład struktury wchodził jeszcze antroponim, którego tu brak.

W tej grupie znajdują się również anonsy, które w kolumnie reklam mogą dziwić, bo w samej nazwie firm nie ma informacji o branży albo — jak w ostatnim z podanych poniżej przykładów - nazwa wręcz jest dezorientująca (firma AUTO handluje sprzętem sportowym). Informacje handlowe są jednaj zazwyczaj podane w dalszej części ogłoszenia, np.:

Zakład ,pod Antygoną” w Wiedniu (CK 23, 1870, nr 282, s. 4).

Fabryka w Polance „Karol” koło Krosna (GL 80, 1900, nr 278, s. 12).

Magazyn mme „Anna” w Krakowie (poleca suknie...) (CK 43, 1890, nr 10, s. 4).

firma „AUTO” Kraków (Już nadszedł transport sprzętów do sportów zimowych do...) (CK 63, 1910, nr 499, s. 4).

${ }^{14}$ Linkteksty to w genologicznej teorii nazw własnych połączenia nazw dopełniających tekst główny (Rutkiewicz-Hanczewska 2013: 324-336). 
Przedstawione tu nazwy coraz bardziej przypominają współczesne ergonimy, które możemy odnaleźć na fasadach budynków, billboardach, plakatach itp.

\section{EWOLUCJA}

Wszystkie omówione powyżej modele nazewnicze pojawiały się w galicyjskich ogłoszeniach prasowych właściwie w całym badanym okresie, lecz z różnym nasileniem. Początkowo najwięcej było określeń wskazujących na właściciela firmy, potem zaczęły przeważać te, w których obok informacji o właścicielu występowało określenie branży przedsiębiorstwa. I takich notacji jest najwięcej - w sumie obejmują one $65 \%$ badanego materiału (zob. wykres 1). Nie jest to zaskakujące, gdyż tak zbudowanym ergonimom można przypisać najwyższy „stopień informatywności nazwy": wiadomo, do kogo należy firma i czym się zajmuje. Te dane, uzupełnione o adres, są wystarczające dla potencjalnego klienta.

Modele ergonimów galicyjskich

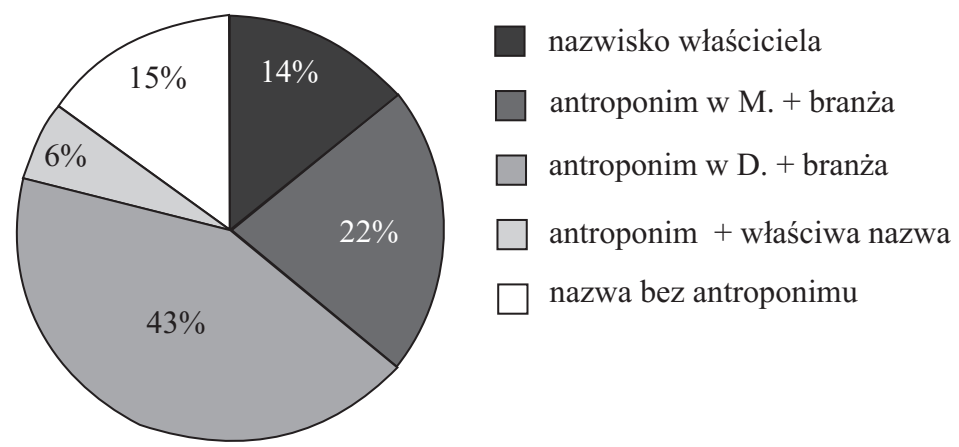

Wykres 1. Produktywność poszczególnych modeli nazewniczych w ergonimach galicyjskich

W opisywanych modelach można zaobserwować pewną ewolucję: od transonimizacji (antroponim przechodzi do klasy ergonimów; powstaje struktura intertekstualna ${ }^{15}$ ), przez deskrypcje określone (antroponim w mianowniku + określenie branży — struktura tylko względnie stabilna), do stałego, powtarzalnego modelu onimicznego (antroponim w dopełniaczu + branża). Ponieważ jednak nazwy te nie były zarejestrowanymi znakami towarów, nie były jeszcze stałe. Co za tym idzie - funkcjonowały w wielu wariantach, a wariancja dotyczyła zarówno postaci graficznej, formy fleksyjnej antroponimu (np. mianownik — dopełniacz), jak i szyku czy nawet leksyki, np.:

15 W tekstologicznej teorii nazw własnych tak określane są miana powstałe w efekcie wtórnego wykorzystania istniejących już nazw; por. Rutkiewicz-Hanczewska 2013: 129-190. 
Materiały jedwabne Marya Prauss (CK 63, 1910, nr 50, s. 6).

Skład płócien MARYA PRAUSS (CK 63, 1910, nr 54, s. 4).

Okrycia Damskie Mary Prauss, Kraków (CK 63, 1910, nr 58, s. 4).

Młoda firma JAN TOMS poleca (m.in. słoninę i smalec) (GR 4, 1900, nr 5, s. 4).

Handel Jana Tomsa w Rzeszowie (art. spożywcze) (GR 4, 1900, nr 49, s. 6).

HANDEL p.f. K. SALWACH (dawniej H. Wierzycki) (GR 14, 1910, nr 40, s. 4).

HANDEL K. SALWACHA w Rzeszowie (GR 14, 1910, nr 49, s. 4).

Warto jeszcze podkreślić znaczenie właściciela firmy, który swoim nazwiskiem gwarantował rzetelność. Dlatego - jeśli spółkę przejmował nowy przedsiębiorca - przynajmniej przez jakiś czas starał się w nazwie akcentować ciągłość interesów, a czynił to przez podawanie w ogłoszeniach nowej i starej afiliacji, np.:

MAGAZYN MEBLI i Zakład tapicersko-dekoracyjny Niemczynowski i Ska dawniej Stanisław Stachowski (CK 63, 1910, nr 401, s. 8).

HANDEL p.f. K. SALWACH (dawniej H. Wierzycki) (GR 14, 1910, nr 40, s. 4).

Fabryka Kapeluszy słomkowych Schwendenwein et Comp. Dawniej R. Morawski w Wiedniu (CK 23, 1870, nr 80, s. 4).

M. Bałłabana następca Mikołaj Ludwig we Lwowie (skład maszyn do szycia) (GL 80, 1890, nr 110, s. 12).

Magazyn Zabawek W.C. Angelusa dawniej F. Bruno Hahn w Krakowie (CK 43, 1890, nr 280, s. 4).

Modele, które wykształciły się później, to, po pierwsze, nazwy, w których brak nazwiska właściciela. Były to głównie różnego rodzaju spółki i towarzystwa, wcześniej firmowane przez pojedynczego właściciela, co czasami jest nawet utrwalone w nazwie, np.:

Pierwsze galicyjskie Towarzystwo akc. dla przemysłu chemicznego /przedtem „Spółka komandytowa Juliana Wanga"/ we Lwowie (GL 80, 1900, nr 195, s. 12).

Po drugie, są to nazwy w postaci linktekstów, zawierające część opisową i właściwą nazwę - markę. Tego rodzaju miana łączą funkcję informacyjną i reklamową, mają bowiem już nie tylko znakować firmę, ale także budzić określone konotacje. Są wprawdzie wśród nich miana bazujące na antroponimach, ale nie wskazują one jednoznacznie na właściciela, np.:

Warszawska Pracownia Gorsetów „Franciszka” (CK 63, 1910, nr 52, s. 4).

Fabryka w Polance „Karol” koło Krosna (GR 1900, nr 278, s. 12).

Większość z nich spełnia warunek, że nazwa-marka ma być krótka, łatwa do zapamiętania, nasuwać przyjemne skojarzenia, uspokajać. Wykorzystuje się przy tym 
m.in. język francuski (Francuzki były uważane za największe elegantki) i łaciński (wyznacznik lepszego wykształcenia, erudycji) ${ }^{16}$, np.:

„LOUVRE” Kraków (sklep odzieżowy) (CK 53, 1900, nr 300, s. 6).

Hurtownia przyborów do palenia „L'Etoile” Michał Hackel (GL 110, 1920, nr 174, s. 8).

Pierwsze przedsiębiorstwo pogrzebowe „Concordia” (CK 33, 1880, nr 230, s. 4).

FABRYKA opatrunków chirurgicznych „VIS” (Mra. M.L. Dobrowolskiego) w Podgórzu-Krakowie (CK 63, 1910, nr 54, s. 4).

O tym, że nazwy-linkteksty były jeszcze słabo utrwaloną strukturą, dopiero pojawiającą się w grupie ergonimów w Galicji, świadczą wcale nierzadkie wahania pomiędzy strukturą opisową i tą z ,nazwą w nazwie”, np. w sierpniowym numerze „Gazety Lwowskiej” z 1920 r. na jednej stronie odnajdujemy dwa ogłoszenia tej samej firmy, reklamujące różne towary:

Hurtownia przyborów do palenia „L'Etoile” Michał Hackel.

Hurtownia firmy Michał Hackel Lwów — Mydła toaletowe (GL 110, 1920, nr 174, s. 8).

\section{SPECYFIKA GALICYJSKICH ERGONIMÓW}

Analizowane zapiski (nazwy i protonazwy) są zupełnie różne od innych nazw funkcjonujących w przestrzeni miasta (urbanonimów). W grupie ergonimów niewiele jest nazw lokalizujących, wskazujących na położenie firmy, a jeśli już są, to wskazują raczej na region czy konkretne miasto, a nie na określony punkt w mieście. Brak tu także nazw charakteryzujących wygląd obiektów (sklepów, zakładów produkcyjnych) - a przecież oba typy nazw są obecne wśród współczesnych emporionimów, które, z jednej strony, informują o obiekcie, a z drugiej — o kreatorze nazwy (por. Siwiec 2012: 72). W ergonimach galicyjskich na plan pierwszy wysuwa się motywacja posesywna.

Jeśli przyjrzymy się budowie analizowanych mian, zauważymy, że — podobnie jak we współczesnych określeniach z tej grupy — brak wyraźnie wyodrębniających się członów o funkcji wyłącznie gatunkowej; jeśli w ogóle takowe są, charakteryzują na równi z pozostałymi członami. Obecność antroponimów w podstawach nazw przedsiębiorstw zbliża je do nazw miejscowych czy nazw ulic, placów, mostów itp., ale tylko w zakresie tworzywa genetycznego, gdyż motywację mają zupełnie inną - współcześnie w urbanonimach nie utrwala się właścicieli obiektów, ale obiekty stają się swoistymi pomnikami zasłużonych.

Galicyjskie nazwy pokazują że Polacy byli (i nadal są) tradycjonalistami. W ergonimach starano się podkreślić ciagłość firmy mimo zmiany właściciela (najczę-

${ }^{16}$ Również współcześnie $\mathrm{w}$ nazewnictwie firmowym modne jest nawiązywanie do internacjonalizmów; obce czy inne postrzegane jest jako innowacyjne, przyciagające uwagę; por. Rutkiewicz-Hanczewska 2014: 138. 
ściej zmiany pokoleniowej). Także współcześnie zauważa się tendencje do akcentowania „doświadczenia” firmy czy opierania się na starych recepturach, umieszczania firmy w starych lokalach (Stary Młyn, Stary Browar — kawiarnie, dyskoteki itp.). Można nawet zauważyć tendencję do pewnej desyntetyzacji w tym zakresie — za tradycyjne uznaje się np. firmy działające już (!) pięć lat.

Choć w tym samym czasie obserwuje się istnienie podobnych struktur nazewniczych, widać, że na początku analizowanego okresu dominują antroponimy w funkcji ergonimów, z czasem pojawiają się coraz liczniej deskrypcje określone, a im bliżej przełomu XIX i XX stulecia, tym więcej notuje się nazw właściwych — stałych, $\mathrm{z}$ dominującą funkcją reklamowa, odsuwającą na drugi plan funkcję informacyjną. Warto przy tym podkreślić „konserwatyzm nazewniczy” aptek, księgarń i drukarń, które w przytaczanych tu ogłoszeniach zawsze są sygnowane nazwiskiem pojedynczego właściciela. Nazwę mogą ,wzbogacać” inne elementy (np. godło, branża), ale nawet jeśli zdarzają się w tej grupie przedsiębiorstw spółki, w nazwie utrwalone zostają dwa nazwiska (ojciec i syn, bracia); bez antroponimu te nazwy nie występują.

Najstarsze galicyjskie nazwy i protonazwy są realistyczne, obiektywne w tym sensie, że nie odnoszą do odległych, subiektywnych konotacji związanych z obiektem czy branżą, nie dotyczą jednostkowych asocjacji, nie odwołują się do osobistych doświadczeń nazywającego, jak to dzieje się we współczesnych emporionimach (por. Siwiec 2012: 71), ale odsyłają do właściciela i informują o branży, w której dana firma działa.

\section{LITERATURA}

Gałkowski A. 2011: Chrematonimy w funkcji kulturowo-użytkowej, Wyd. UŁ, Łódź.

Górny H. 2003: Tendencje onimiczne w nazwach krakowskich aptek, „Acta onomastica” XLIV, s. 15-28 .

Górny H. 2005: Semantyka i struktura nazw aptek w Rzeszowie, [w:] J. Pasterska, R. Mnich, E. Pszenyczny (red.), „Studia Philologica. Rozprawy i szkice”, s. 267-274.

Kruk D. P. 2015: Instytucjonalne formy wspierania rozwoju przemystu Galicji w dobie autonomii, „Zeszyty Naukowe UE w Krakowie” 6 (942), s. 93-105, https://zeszyty-naukowe.uek.krakow.pl/ article/download/518/250

Mianowski H. 1938: Rola ustawodawstwa przemystowego w rozwoju rzemiosła z uwzględnieniem aktualnych tendencji nowelizatorskich, nakładem autora, Kraków.

Pabis-Braunstein M. 1986: Godta polskich aptek zabytkami rodzimej kultury, „Ochrona Zabytków” I, z. 1, s. 113-120.

Rutkiewicz-Hanczewska M. 2013: Genologia onimiczna. Nazwa własna w płaszczyźnie motywacyjno-komunikatywnej, Wyd. Poznańskie, Poznań.

Rutkiewicz-Hanczewska M. 2014: Moda w zakresie morfologii wspótczesnych emporionimów, „Poznańskie Spotkania Językoznawcze” 27, s. 135-144, http://pressto.amu.edu.pl/index.php/psj/ article/view/632/550.

Siwiec A. 2012: Nazwy własne obiektów handlowo-uslugowych w przestrzeni miasta, Wyd. UMCS, Lublin. 
http://www.zakladamyfirme.pl/artykul_narzedziowa,643,643,646,spolka-cywilna-najtansza-wzalozeniu-i-prowadzeniu.html (dostęp 25 VIII 2016).

https://prod.ceidg.gov.pl/CEIDG/CEIDG.Public.UI/Forms/CEIDG1.aspx?type=1 (dostęp 25 VIII 2016).

http://www.sp-z-oo.pl/ (dostęp 25 VIII 2016).

http://sjp.pwn.pl/sjp (dostęp IX 2016).

\section{SKRÓTY BIBLIOGRAFICZNE}

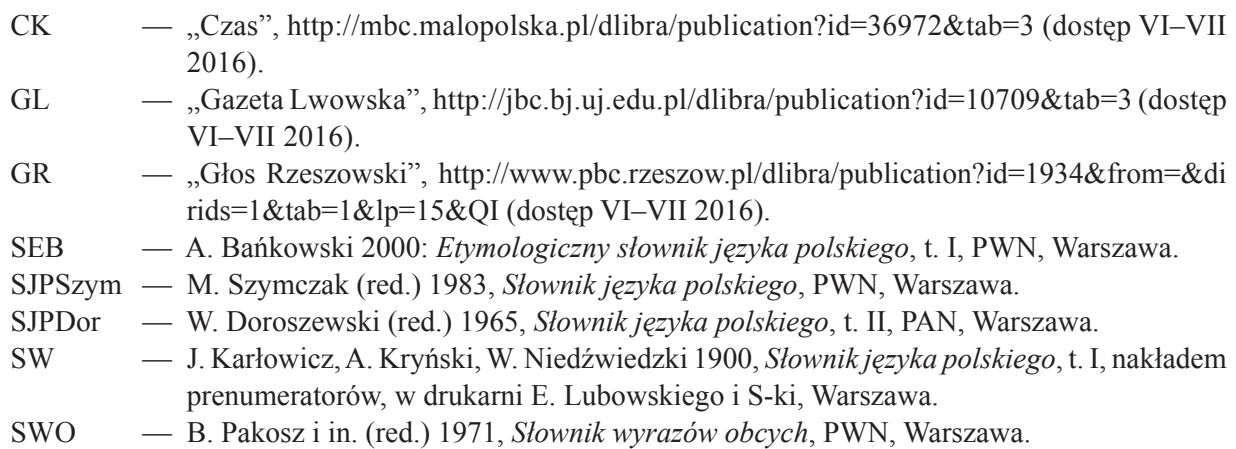

\section{FROM DEFINITE DESCRIPTION TO ERGONYM — GALICIAN NAMES OF ENTERPRISES}

\section{SUMMARY}

This paper presents names of companies taken from three dailies published in Galicia in the second half of the nineteenth century and at the beginning of the twentieth century: "Czas Krakowski", "Gazeta Lwowska", and "Głos Rzeszowski". The collected material includes nearly 400 units.

The objective of the analysis was to show how names of companies were formed in the 19th century, which elements of non-linguistic reality were most often used as components of ergonyms, and how the names of the companies were built. An analysis proved that motivation of the names determines their structure to a great extent, and that one can divide the analysed names into two groups: 1. Ergonyms reflecting last name(s) of the owner, 2. Names that do not include any personal names.

Observation of evolution in this group of names within a period of several dozen years of Galician autonomy within Austria-Hungary showed that although all models of names that are discussed in the paper were present in the press advertisements in Galicia in the whole period under analysis, they appeared with various intensity. At first, most names disclosed who the owner was. Then, majority of names of the companies also added the information about the sector in which the company operated. Later, names without any indication of the owner's name became popular. Another category of popular names were those in a form of linktexts including a descriptive part and the proper name (a brand) in their structure.

Ke y w ord s: Galicia, ergonym, description, press advertisements 